\title{
THỰC HÀNH DINH DƯỠNG VÀ BỮA PHỤ TÓI MUỌN CỦA NGƯỜI BỆNH XO' GAN TẠI BỆNH VIỆN ĐẠI HỌC Y HÀ NỘ NĂM 2020
}

\author{
Nguyễn Thùy Linh, Phạm Thị Tuyết Chinh và Nguyễn Thị Minh Tâm
}

Bệnh viện Đại học Y Hà Nội

Nghiên cứu nhằm mô tả thực hành dinh dương và bữa phụ tối muộn của người bệnh xơ gan tại Bệnh viện Đại học Y Hà Nội năm 2020. Thiết kế nghiên cứu mô tả cắt ngang trên 40 người bệnh xơ gan từ tháng 12 năm 2019 đến tháng 04 năm 2020. Nghiên cứu cho thấy 22,5\% có sử dụng bữa phụ buổi tối muộn, tuy nhiên năng lượng và thành phần dinh dưỡng trong bữa phụ tối muộn chưa đạt nhu cầu khuyến nghị với năng lượng là 140,4 Kcal, protein là 5,09 \$2,53g; lượng glucid là 19,1g. Khẩu phần $24 h$ đạt nhu cầu khuyến nghị chiếm 27,5\%. Tỷ lệ người bệnh thực hành đúng hạn chế tiêu thụ rượu, bia là 67,5\%; thực hành đúng 4 - 6 bữa/ngày là 27,5\%. Thực hành dinh dướng trên ngươ bệnh xơ gan rất quan trọng, vì vậy cần tăng cường tư vấn, giáo dục về dinh dưỡng để nâng cao hiệu quả điều trị.

Từ khóa: Thực hành dinh dưỡng, bữa phụ tối muộn, xơ gan, Bệnh viện Đại học Y Hà Nội.

\section{I. ĐẠT VẤN ĐÊ}

Xơ gan là một bệnh lý phổ biến với tỷ lệ mắc và tử vong cao. ${ }^{1}$ Theo báo cáo ước tính sức khỏe toàn cầu (Global Health Estimates) năm 2016, xơ gan là nguyên nhân tử vong phổ biến đứng thứ 11 mỗi năm trên thế giới với $2,1 \%$ tổng số người chết. ${ }^{2}$

Ở Việt Nam, tỷ lệ xơ gan khá cao so với thế giới, tỷ lệ này đang có xu hướng gia tăng và gây nên nhiều biến chứng nguy hiểm. Theo thống kê của Tổ chức $Y$ tế Thế giới (WHO), Việt Nam có tỷ lệ mắc bệnh xơ gan chiếm $5 \%$ dân số, trong đó xơ gan do virus chiếm $40 \%$ và xơ gan do rượu chiếm $18 \%$. Số ca tử vong chiếm đến $3 \%$ trong tổng số ca do bệnh tật gây ra ${ }^{3}$. Trên thế giới ngày càng nhận ra tầm quan trọng của việc kiểm soát các yếu tố nguy cơ như uống rượu, viêm gan siêu vi $B$ và $C$ mạn tính.

Suy dinh dưỡng thường gặp ở người bệnh xơ gan, đặc biệt là ở giai đoạn nặng của bệnh,

Tác giả liên hệ: Nguyễn Thị Minh Tâm

Trường Đại học Y Hà Nội

Email: minhtamhmu@gmail.com

Ngày nhận: 14/09/2021

Ngày được chấp nhận: 13/10/2021 tỷ lệ này tăng từ $20 \%$ ở giai đoạn còn bù và lên tới hơn $60 \%$ ở giai đoạn tiến triển. ${ }^{4}$ Nhiều biểu hiện chuyển hóa bất thường ở người bệnh xơ gan có thể góp phần tác động đến tình trạng dinh dưỡng. Đặc biệt, sau khi nhịn ăn qua đêm, người bệnh xơ gan có biểu hiện tăng tốc độ oxy hóa chất béo và tạo gluconeogenes trong khi việc sử dụng glucose và phân giải glycogenolysis giảm so với bình thường. ${ }^{5}$ Các nghiên cứu gần đây đã chỉ ra rằng bữa ăn nhẹ buổi tối muộn (Late eating snack - LES) mang lại nhiều lợi ích cho người bệnh, giúp người bệnh không bị hạ đường huyết vào giữa đêm, cải thiện cân bằng nitơ, giảm quá trình dị hoá protein và tránh suy mòn $\operatorname{cơ}^{6,7}$ Do đó, năm 2002, Hiệp hội Dinh dưỡng tĩnh mạch Hoa Kỳ (ASPEN) khuyến cáo rằng bệnh nhân xơ gan nên chia khẩu phần ăn thành 4 đến 6 bữa mỗi ngày, bao gồm cả bữa ăn nhẹ buổi tối muộn. ${ }^{8}$

Việc tin tưởng và lựa chọn một chế độ ăn phù hợp trong thời gian điều trị bệnh đóng vai trò quan trọng góp phần cải thiện tình trạng dinh dưỡng và phòng ngừa các biến chứng. Tuy nhiên, nghiên cứu đánh giá về thực hành dinh dưỡng hợp lý ở người bệnh xơ gan còn 
hạn chế. Do đó, chúng tôi tiến hành nghiên cứu đề tài "Thực hành dinh dưỡng và bữa phụ tối muộn ở người bệnh xơ gan tại Bệnh viện Đại học Y Hà Nội năm 2020" với mục tiêu: Mô tả thực hành dinh dưỡng và bữa phụ tối ở người bệnh xơ gan tại Bệnh viện Đại học Y Hà Nội năm 2020.

\section{II. ĐỐI TƯƠ'NG VÀ PHƯƠNG PHÁP}

\section{1. Đối tượng}

Người bệnh từ 18 tuổi trở lên, được chẩn đoán xơ gan tại Bệnh viện Đại học Y Hà Nội, thời gian nghiên cứu từ tháng 12 năm 2019 đến tháng 04 năm 2020.

\section{Tiêu chuẩn lựa chọn}

- Đối tượng là người trưởng thành từ 18 tuổi trở lên được chẩn đoán xơ gan mã ICD K74.

- Đối tượng được giải thích đầy đủ và đồng ý tham gia nghiên cứu.

\section{Tiêu chuẩn loại trù̀}

- Đối tượng có hội chứng não gan, xuất huyết tiêu hóa, suy gan cấp, ung thư biểu mô tế bào gan nằm trong nhóm biến chứng dẫn đến thay đổi chế độ ăn và có sự theo dõi sát của nhân viên y tế.

- Đối tượng không thể thu thập được số liệu do câm, điếc và dị tật.

\section{Phương pháp}

\section{Thiết kế nghiên cứru}

Nghiên cứu mô tả cắt ngang.

\section{Cỡ mẫu và chọn mẫu}

Chọn mẫu thuận tiện, nghiên cứu từ tháng 9/2019 đến tháng 4/2020. Nghiên cứu chọn tối đa tất cả người bệnh đạt tiêu chuẩn theo danh sách người bệnh vào viện trong vòng 24 giờ đầu. Cỡ mẫu cuối cùng thu được là 40 người bệnh.

\section{Các biến số và chỉ số}

- Thực hành bữa phụ tối muộn: là việc cung cấp năng lượng sau 8 giờ tối, tỷ lệ người bệnh ăn bữa phụ buổi tối muộn, năng lượng, thành phần chất dinh dưỡng protein, glucid bưa phụ tối muộn so với nghiên cứu của Tsien và cộng sự, năng lượng là $200 \mathrm{Kcal}$, lượng glucid cho bữa phụ tối muộn là $50 \mathrm{~g} .{ }^{9}$ Lượng protein cho bữa phụ tối muộn là $15 \mathrm{~g}$ theo nghiên cứu của Kalla và cộng sự. ${ }^{10}$

- Thực hành dinh dưỡng trong bệnh xơ gan:

Năng lượng khẩu phần ăn 24 giờ: Điều tra viên hỏi ghi tất cả các thực phẩm (kể cả đồ uống) được người bệnh tiêu thụ trong 24h kể từ lúc phỏng vấn trở về trước. Các phương tiện sử dụng: quyển ảnh điều tra khẩu phần, bảng thành phần thực phẩm Việt Nam, quyển hệ số sống chín và bảng quy đổi trọng lượng thực phẩm, bản chi tiết giá trị dinh dưỡng các thực phẩm bổ sung dinh dưỡng...

Thành phần các chất dinh dưỡng: sau khi xử lý số liệu từ khẩu phần $24 \mathrm{~h}$ được tính toán năng lượng, các chất dinh dưỡng của người bệnh dựa trên bảng thành phần hóa học thực phẩm Việt Nam.

Thực hành dinh dưỡng: dựa trên bộ câu hỏi tần suất tiêu thụ thực phẩm trong tuần của người bệnh so với tần suất trước đây chia thành ba mức độ:

+ Tăng tiêu thụ: sử dụng hàng ngày hoặc 4 - 6 lần/tuần,

+ Không thay đổi,

+ Hạn chế sử dụng: < 3 lần/tuần.

\section{Xử lý số liệu}

Cách khống chế sai số trong quá trình thu thập số liệu: phiếu nghiên cứu được thử nghiệm trước khi tiến hành nghiên cứu, đảm báo chính xác thông tin trong hồ sơ bệnh án, số liệu thu thập và xử lý cẩn thận, nghiêm túc.

Số liệu sau khi thu thập được làm sạch và nhập vào máy tính bằng phần mềm Epidata 3.1. Các phân tích được thực hiện bằng phần mềm Stata 15.0. Các biến số được mô tả bằng tỷ lệ 
phần trăm, giá trị trung bình, độ lệch. Sử dụng kiểm định T-test để so sánh các giá trị trung bình.

\section{4. Đạo đức nghiên cứu}

Đối tượng nghiên cứu được giải thích rõ ràng về mục đích, ý nghĩa của nghiên cứu và

\section{KÉT QUẢ}

Nghiên cứu gồm 40 người bệnh, nam chiếm $87,5 \%$, nữ 12,5\%, nhóm tuổi trên 60 tuổi chiếm tỷ lệ cao nhất $50 \%$. Người bệnh xơ gan do rượu tự nguyện tham gia nghiên cứu. Các thông tin thu thập được chỉ phục vụ cho mục đích nghiên cứu. Nghiên cứu được sự đồng ý của lãnh đạo Bệnh viện và lãnh đạo khoa/phòng có người bệnh tham gia nghiên cứu.

\section{Thực hành ăn bữa phụ tối muộn của người bệnh xơ gan}

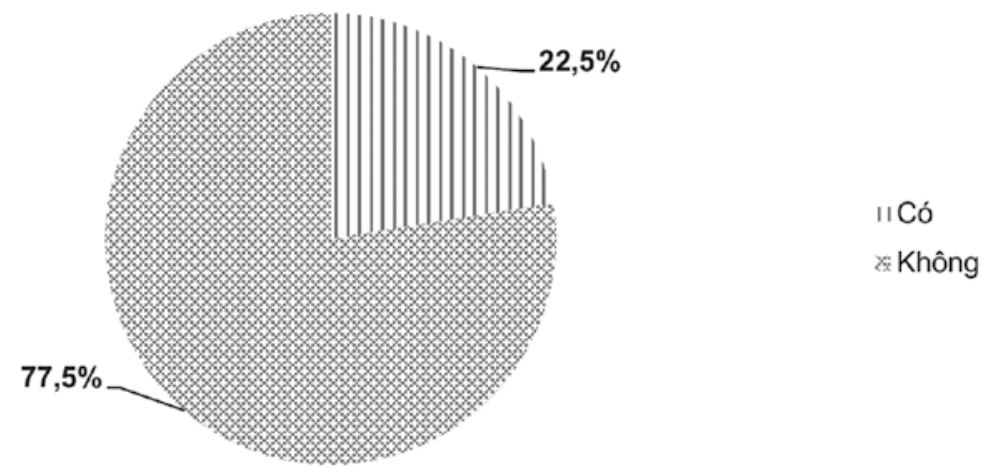

Biểu đồ 1. Tỷ lệ thực hành bữa phụ tối muộn của người bệnh xơ gan

Biểu đồ 1 cho thấy tỷ lệ người bệnh ăn bữa phụ tối muộn chiếm 22,5\%; số người bệnh không ăn bữa phụ tối muộn là $77,5 \%$.

Bảng 1. Đặc điểm bữa phụ tối muộn của người bệnh xơ gan

\begin{tabular}{ccccc}
\hline & Nam $(\mathbf{n}=\mathbf{7})$ & Nũ $(\mathbf{n}=\mathbf{2})$ & Chung $(\mathbf{n = 9})$ & $\mathbf{P}^{\#}$ \\
\hline Năng lượng $($ Kcal) & $151,7 \pm 65,1$ & $101 \pm 11,3$ & $140,4 \pm 60,7$ & 0,33 \\
\hline Glucid $(\mathrm{g})$ & $19,0 \pm 10,4$ & $19,6 \pm 1,6$ & $19,1 \pm 9,0$ & 0,94 \\
\hline Protein $(\mathrm{g})$ & $5,78 \pm 2,35$ & $2,65 \pm 1,63$ & $5,09 \pm 2,53$ & 0,06 \\
\hline
\end{tabular}

\#: T test

Bảng 1 cho thấy năng lượng, protein, glucid tiêu thụ trong bữa phụ tối muộn lần lượt là 140,4 $\pm 60,7 \mathrm{Kcal} ; 5,09 \pm 2,53 \mathrm{~g}$ và $19,1 \pm 9,0 \mathrm{~g}$. Có sự khác biệt về lượng đạm tiêu thụ giữa nam và nữ, tuy nhiên sự khác biệt này không có ý nghĩa thống kê với $p=0,06$. 
2. Thực hành dinh dưỡng của người bệnh xơ gan

Bảng 2. Đặc điểm khẩu phần ăn trong 24h của người bệnh xơ gan

\begin{tabular}{|c|c|c|c|c|}
\hline & $\bar{X} \pm S D$ & Min - Max & $\begin{array}{c}\text { Nhu cầu khuyến } \\
\text { nghị (NCKN) }\end{array}$ & $\begin{array}{c}\text { Tỷ lệ người bệnh } \\
\text { đạt NCKN(\%) }\end{array}$ \\
\hline $\begin{array}{l}\text { Năng lượng } \\
\text { (Kcal/ngày) }\end{array}$ & $1445,9 \pm 727,7$ & $151-3395,3$ & $1657-1933,2$ & $27,5 \%$ \\
\hline Protein (g) & $58,7 \pm 31,7$ & $7,8-145,9$ & $55,2-66,3$ & $52,5 \%$ \\
\hline Lipid (g) & $30,1 \pm 22$ & $3,2-121,8$ & $27,6-53,7$ & $67,5 \%$ \\
\hline Glucid (g) & $235,2 \pm 118,2$ & $20,2-472$ & $207,1-290$ & $97,5 \%$ \\
\hline Chất xơ (g) & $5,6 \pm 3,5$ & $0,24-15,6$ & 20 - 30g/ngày & $0 \%$ \\
\hline Vitamin B1 (mg) & $1,2 \pm 0,45$ & $0,7-1,6$ & 1,1 mg/ngày & $62,5 \%$ \\
\hline \multirow[t]{3}{*}{ Sắt (mg) } & $9,6 \pm 5,7$ & $0,8-24,2$ & & - \\
\hline & $9,9 \pm 5,6$ & $0,8-24,2$ & Nam: 7,9 mg/ngày & $60 \%$ \\
\hline & $7,3 \pm 6,1$ & $2,8-18,1$ & Nũ: 6,7 mg/ngày & $40 \%$ \\
\hline \multirow[t]{3}{*}{ Kẽm (mg) } & $8,0 \pm 3,05$ & $5,3-11,4$ & & - \\
\hline & $8,8 \pm 2,9$ & $5,7-11,4$ & Nam: 10 mg/ngày & $40 \%$ \\
\hline & $4,5 \pm 2,5$ & $3,1-8,1$ & Nữ: 8 mg/ngày & $60 \%$ \\
\hline
\end{tabular}

Bảng 2 cho thấy năng lượng trung bình trong khẩu phần ăn $24 \mathrm{~h}$ của đối tượng nghiên cứu là 1445,9 \pm 727,7 Kcal. Năng lượng khẩu phần ăn của đối tượng đáp ứng nhu cầu khuyến nghị còn ở mức thấp (chiếm 27,5\%), vitamin B1 đạt $62,5 \%$. Các khoáng chất như sắt, kẽm có lượng trung bình lần lượt là $9,6 \mathrm{~g}$ và $8 \mathrm{~g}$. Không có đối tượng nào đáp ứng đủ nhu cầu chất xơ trong khẩu phần ăn.

Bảng 3. Thụ̣c hành dinh dưỡng ở người bệnh xơ gan

\begin{tabular}{lccc}
\hline Thực hành tăng cường các thực phẩm & Tăng tiêu thụ & Không thay đổi & Giảm tiêu thụ \\
\hline & Số lượng (\%) & Số lượng (\%) & Số lượng (\%) \\
\hline Carbohydrate & $3(7,5 \%)$ & $35(87,5 \%)$ & $2(5 \%)$ \\
\hline Protein động vật & $4(10 \%)$ & $16(40 \%)$ & $20(50 \%)$ \\
\hline Protein thực vật & $4(5 \%)$ & $36(95 \%)$ & $0(0 \%)$ \\
\hline Rau củ mềm ít xơ & $10(25 \%)$ & $27(67,5 \%)$ & $3(7,5 \%)$ \\
\hline Hoa quả & $15(37,5 \%)$ & $23(57,5 \%)$ & $2(5 \%)$ \\
\hline
\end{tabular}




\begin{tabular}{lccc}
\hline Thực hành hạn chế các thực phẩm & Tăng tiêu thụ & Không thay đổi & Giảm tiêu thụ \\
\hline & Số lượng (\%) & Số lượng (\%) & Số lượng (\%) \\
\hline Chất béo, thực phẩm nhiều chất béo & $0(0 \%)$ & $26(65 \%)$ & $14(35 \%)$ \\
\hline Rượu, bia & $0(0 \%)$ & $13(32,5 \%)$ & $27(67,5 \%)$ \\
\hline Đồ ngọt, nước có ga & $3(7,5 \%)$ & $31(77,5 \%)$ & $8(15 \%)$ \\
\hline
\end{tabular}

Bảng 3 cho thấy kết quả nghiên cứu cho thấy tỷ lệ hạn chế sử dụng rượu, bia, đạm động vật, và chất béo, các thực phẩm nhiều chất béo ở người bệnh xơ gan cao nhất lần lượt là
$67,5 \%, 50 \%$ và $35 \%$. Bên cạnh đó, tỷ lệ người bệnh tăng sử dụng rau củ là $25 \%$ và hoa quả là $37,5 \%$.

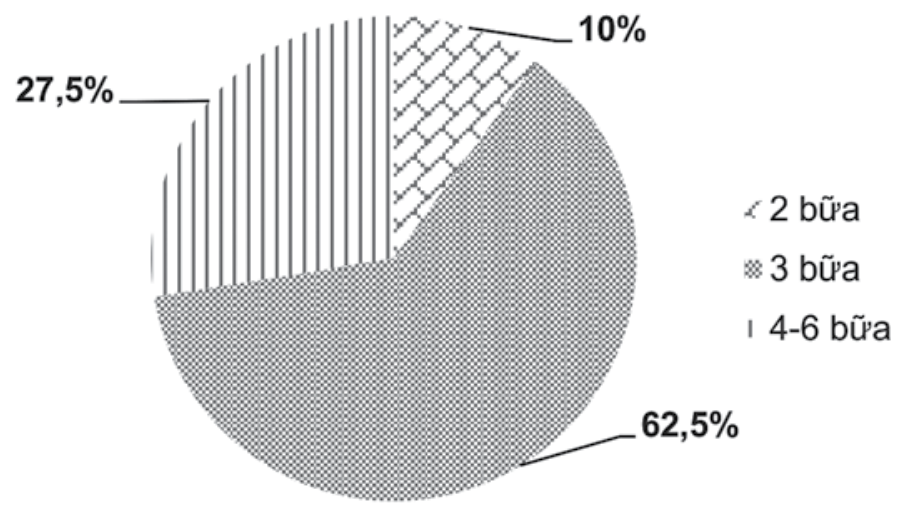

\section{Biểu đồ 2. Phân bố số bữa ăn trong ngày của người bệnh xơ gan}

Biểu đồ 2 cho thấy chế độ ăn 3 bữa/ngày chiếm tỷ lệ cao nhất là $62,5 \%$, tỷ lệ người bệnh ăn 4 - 6 bữa/ngày là $27,5 \%$, có tới $10 \%$ người bệnh chỉ ăn 2 bữa/ngày.

\section{BÀN LUÂN}

Kết quả nghiên cứu cho thấy có $22,5 \%$ người bệnh ăn bữa phụ tối muộn. Trung bình năng lượng, lượng glucid và protein người bệnh ăn bữa phụ tối muộn lần lượt là 140,4 Kcal; 19,1g; $5,78 \mathrm{~g}$. Kết quả này thấp hơn nghiên cứu của Tsien và cộng sự. ${ }^{9}$ Lượng protein tiêu thụ giữa nam và nữ có sự khác nhau, tuy nhiên sự khác biệt không có ý nghĩa thống kê với $p=0,06$. Lượng protein trong nghiên cứu cũng thấp hơn so với nghiên cứu của Kalla và cộng sự $(15 \mathrm{~g}) .{ }^{10}$ Kết quả hai nghiên cứu của Tsien và Kalla cho thấy bữa ăn phụ tối muộn giúp cải thiện cân bằng nitơ, giảm quá trình dị hoá protein, hạn chế hạ đường huyết vào ban đêm ở người bệnh xơ gan.

Về thực hành dinh dưỡng của người bệnh, kết quả khẩu phần ăn $24 \mathrm{~h}$ của người bệnh trong nghiên cứu cho thấy, năng lượng trung bình 1445,9 $\pm 727,7$ Kcal/ngày thấp hơn hướng dẫn điều trị dinh dưỡng lâm sàng Việt Nam năm 2016. ${ }^{11}$ Do bệnh lý xơ gan liên quan đến các chuyển hóa bất thường, tăng dị hóa và thực thế, người bệnh xơ gan có lượng thức ăn giảm do các triệu chứng của bệnh và các hạn chế về chế 
độ ăn uống. Tổng năng lượng trung bình trong nghiên cứu này khá giống với nghiên cứu của Daphnee và cộng sự năm 2017 là 1540,79 \pm 309,3 Kcal/ngày. ${ }^{12}$ Lượng chất đạm trung bình trong khẩu phần của người bệnh chỉ đáp ứng $52,5 \%$ nhu cầu khuyến nghị theo hướng dẫn dinh dưỡng lâm sàng Việt Nam năm 2016. Về protein trước đây đã có nhiều tranh cãi về việc liệu người bệnh xơ gan giai đoạn nặng hoặc bệnh não gan có nên giảm protein tạm thời nhằm hạn chế sự tổng hợp amoni và sự khử acid amin của protein thành các acid amin thơm hay không. Tuy nhiên, các nghiên cứu gần đây đã chỉ ra rằng việc tăng lượng đạm thường dung nạp tốt, cải thiện quá trình đồng hóa protein, người bệnh xơ gan giai đoạn mất bù không cần hạn chế protein, thậm chí người bệnh xơ gan có suy dinh dưỡng cần tăng lượng protein. Việc hạn chế protein chỉ áp dụng cho người bệnh có hội chứng não gan. ${ }^{7,13}$ Đối với các khoáng chất, nồng độ kẽm thường giảm ở người bệnh xơ gan, đặc biệt là nguyên nhân xơ gan do rượu. Thiếu kẽm dẫn đến chán ăn, thay đổi vị giác góp phần làm giảm lượng ăn vào do dẫn đến các nguy cơ dinh dưỡng. Lượng sắt ăn vào của người bệnh cao hơn ở cả hai giới. Gan là nơi sản xuất phần lớn các protein tham gia vào quá trình chuyển hóa sắt bao gồm hepcidin và transferrin, khi gan bị tổn thường dẫn đến sự tích tụ sắt, tác động của tình trạng thừa sắt ở gan liên quan đến sự tiến triển của bệnh và sự hình thành ung thư gan. ${ }^{14}$ Kết quả nghiên cứu có thể giải thích do lượng thịt đỏ người bệnh tiêu thụ hàng ngày vẫn ở mức cao và một số người bệnh cho rằng cần ăn tăng để đảm bảo năng lượng. Trong nghiên cứu không có người bệnh nào đáp ứng nhu cầu về chất xơ theo khuyến cáo của Viện Dinh dưỡng Quốc gia (20 - 30g/ngày), trong khi tỷ lệ tiêu thụ rau xanh và hoa quả đã tăng lên. ${ }^{15}$ Chất xơ hoạt động như một prebiotic thúc đẩy sự phát triển của các vi khuẩn có lợi, hạn chế sự phát triển của vi khuẩn có hại và các chất chuyển hóa có hại của chúng, đồng thời tăng vận chuyển đường ruột có lợi với người bệnh xơ gan.

Ngoài ra, những thực phẩm nên sử dụng như hoa quả, rau củ mềm ít xơ chiếm tỷ lệ cao nhất lần lượt là $37,5 \%$ và $25 \%$. Tỷ lệ này thấp hơn nghiên cứu của Nguyễn Thanh Liêm. ${ }^{16}$ Người bệnh thực hành dinh dưỡng chưa đúng khi không thay đổi chế độ ăn tăng carbohydrat (87,5\%), và hạn chế đạm động vật $(50 \%)$. Một chế độ ăn giảm đạm làm tăng hiện tượng giáng hóa cơ', teo cơ ở người bệnh xơ gan, đạm động vật là nguồn đạm có giá trị sinh học cao, dễ hấp thu, theo khuyến nghị của ESPEN việc tăng sử dụng protein kết hợp với luyện tập hoạt động thể lực giúp người bệnh tăng cường cơ bắp, cải thiện chu vi cánh tay và sức mạnh nắm tay. ${ }^{4}$ Tỷ lệ người bệnh hạn chế rượu, bia và thực phẩm giàu chất béo chiếm tỷ lệ cao trong nhóm thực phẩm nên hạn chế là $67,5 \%$ và $35 \%$. Kết quả này có thể được giải thích do bệnh lý xơ gan có các thay đổi bất thường về chuyển hóa, chế độ ăn giàu chất béo dẫn đến hiện tượng đầy bụng, chán ăn, tăng cường sử dụng rau xanh và hoa quả hàng ngày cũng giúp người bệnh cảm thấy thoải mái và dễ ăn hơn. ${ }^{4}$ Ngoài ra, tỷ lệ người bệnh thực hành 4 - 6 bữa/ngày còn thấp so với khuyến nghị của ASPEN là $27,5 \%{ }^{8}$

Nghiên cứu của chúng tôi đã đưa ra các số liệu về thực hành dinh dưỡng và bữa phụ tối muộn của người bệnh xơ gan. Tuy nhiên, cỡ mẫu còn hạn chế ( 40 người bệnh) do nghiên cứu tiến hành khi tình hình dịch Covid-19 có nhiều diễn biến phức tạp, trải qua nhiều chu kỳ dịch. Nghiên cứu cần được tiếp tục nhằm cung cấp các bằng chứng tin cậy cho việc chăm sóc bệnh nhân xơ gan.

\section{KẾT LUÂN}

Nghiên cứu cho thấy tỷ lệ đối tượng ăn bữa phụ tối muộn thấp với $22,5 \%$, chưa đáp ứng về năng lượng và các chất sinh năng lượng. Trong thực hành dinh dưỡng người bệnh đã hạn chế 
sử dụng rượu, bia, đồ ngọt và nước có ga, tuy nhiên chế độ ăn tăng tinh bột và đạm động vật vẫn chưa có nhiều thay đổi. Khẩu phần $24 \mathrm{~h}$ của đối tượng chỉ đáp ứng 27,5\% nhu cầu khuyến nghị. Cần đẩy mạnh công tác tư vấn, theo dõi và chăm sóc dinh dưỡng cho người bệnh xơ gan tại các cơ sở y tế và cộng đồng, tạo tiền đề cho các nghiên cứu chuyên sâu hơn.

\section{LỜI CẢM ƠN}

Chúng tôi xin chân thành cảm ơn ban lãnh đạo Bệnh viện Đại học $Y$ Hà Nội, các đồng nghiệp và đặc biệt, là người bệnh và gia đình người bệnh đã tạo điều kiện, phối hợp để chúng tôi hoàn thành nghiên cứu này.

\section{TÀI LIẸU THAM KHẢO}

1. GBD 2013 Mortality and Causes of Death Collaborators. Global, regional, and national age-sex specific all-cause and cause-specific mortality for 240 causes of death, 1990-2013: a systematic analysis for the Global Burden of Disease Study 2013. Lancet Lond Engl. 2015;385(9963):117-171. doi:10.1016/S01406736(14)61682-2.

2. WHO Global Health Estimates: Life expectancy and leading causes of death and disability. Accessed July 1, 2021. https://www. who.int/data/gho/data/themes/mortality-andglobal-health-estimates.

3. $\mathrm{WHO} \mid$ Methods and related documentation. WHO. Accessed October 3, 2018. http://www. who.int/healthinfo/global_burden_disease/data_ sources_methods/en.

4. Plauth M, Bernal W, Dasarathy S, et al. ESPEN Guideline on Clinical Nutrition in Liver Disease. Clin Nutr Edinb Scotl. 2019;38(2):485521. doi:10.1016/j.clnu.2018.12.022.

5. Owen OE, Trapp VE, Reichard GA, et al. Nature and quantity of fuels consumed in patients with alcoholic cirrhosis. J Clin Invest.
1983;72(5):1821-1832. doi:10.1172/JCl111142.

6. Toshikuni N, Arisawa T, Tsutsumi M. Nutrition and exercise in the management of liver cirrhosis. World J Gastroenterol. 2014;20(23):7286-7297. doi:10.3748/wjg.v20. i23.7286.

7. Swart GR, Zillikens MC, van Vuure JK, van den Berg JW. Effect of a late evening meal on nitrogen balance in patients with cirrhosis of the liver. BMJ. 1989;299(6709):1202-1203. doi:10.1136/bmj.299.6709.1202.

8. ASPEN Board of Directors and the Clinical Guidelines Task Force. Guidelines for the use of parenteral and enteral nutrition in adult and pediatric patients. JPEN J Parenter Enteral Nutr. 2002;26(1 Suppl):1SA-138SA.

9. Tsien CD, McCullough AJ, Dasarathy S. Late evening snack: exploiting a period of anabolic opportunity in cirrhosis. J Gastroenterol Hepatol. 2012;27(3):430-441. doi:10.1111/ j.1440-1746.2011.06951.x.

10. E-KF Mansor LO, El-Bassat HA, Mishaal $S$, Attia JF. The effect of a late-evening proteincontaining snack on nitrogen balance in cirrhotic patients. Tanta Med J. 2014;(42):47-52.

11. Lê Thị Hương, Trần Thị Phúc Nguyệt. Dinh Dương Lâm Sàng - Tiết Chế. Nhà xuất bản Y học, Hà Nội; 2016.

12. Daphnee DK, John S, Vaidya A, Khakhar A, Bhuvaneshwari S, Ramamurthy A. Hand grip strength: A reliable, reproducible, cost-effective tool to assess the nutritional status and outcomes of cirrhotics awaiting liver transplant. Clin Nutr ESPEN. 2017;19:49-53. doi:10.1016/j. clnesp.2017.01.011.

13. Nielsen K, Kondrup J, Martinsen L, et al. Long-term oral refeeding of patients with cirrhosis of the liver. Br J Nutr. 1995;74(4):557567. doi:10.1079/bjn19950158.

14. Milic S, Mikolasevic I, Orlic L, et al. 
The Role of Iron and Iron Overload in Chronic Liver Disease. Med Sci Monit Int Med J Exp Clin Res. 2016;22:2144-2151. doi:10.12659/ MSM.896494.

15. Viện Dinh dưỡng Quốc gia. Nhu Cầu Dinh Dưỡng Khuyến Nghị Cho Người Việt Nam
Năm 2016.

16. Nguyễn Thanh Liêm,Hà Xuân Mai. Khảo sát thực hành dinh dưỡng và một số yếu tố liên quan của bệnh nhân xơ gan tại khoa nội tiêu hóa bệnh viên đa khoa trung ương Cần Thơ. $Y$ học thực hành. 2013;899(12).

\section{Summary}

\section{NUTRITIONAL PRACTICE AND LATE EVENING SNACK IN CIRRHOTIC PATIENTS AT HANOI MEDICAL UNIVERSITY HOSPITAL, 2020}

This study was aimed to describe the nuttrition practice of patients with liver cirrhosis at $\mathrm{Ha}$ Noi Medical University Hospital in 2020. The cross sectional descriptive study was conducted among 40 cirrhotic patients from December 2019 to April 2020. Results showed that $22.5 \%$ patients had a late-evening snack, but energy and nutrients did not meet the recommended requirements in lateevening snack. Mean energy was $140.4 \mathrm{Kcal}$, protein and glucid of the late-evening snack were 5.09 $\pm 2.53 \mathrm{~g}$ and $19.1 \mathrm{~g}$, respectively. The rate of patients with recommended daily intakes of food was low $(27.5 \%)$. The percentage of patients had good practice in alcohol restriction was $67.5 \%$; appropriate nutrition practices for consumption of 4-6 meals/day was $27.5 \%$.

Keywords: Nutritional practice, late-evening snack, cirrhosis, Ha Noi Medical University Hospital. 